\title{
DEVELOPMENT OF AN EARLY WARNING SYSTEM FOR EVALUATING THE CREDIT PORTFOLIO'S QUALITY. A CASE STUDY ON ROMANIA
}

\author{
lustina Boitan*
}

\begin{abstract}
:
The current financial crisis has boosted the efforts of international financial institutions to strengthen collaboration in the field of banking supervision, with a particular focus on macro prudential supervision. One of the stated objectives is the creation of a warning system, in which economic and financial vulnerabilities at the regional level will be coupled with the potential for spillovers or contagion between markets and countries. The aim of this study is to design an early warning system in order to highlight, at an earlier stage, the likelihood of deterioration of the Romanian banking system credit portfolio's quality. The paper focuses on the relationship between several macroeconomic and bank-specific variables and overdue and doubtful loans. The warning system developed will be used further to made predictions on the degree of credit portfolio impairment, under the auspices of the actual financial crisis.
\end{abstract}

Keywords: early warning system, logistic regression, probability of deterioration of the loan portfolio, goodness-of-fit tests, predictive ability

JEL Classification: G01, G21

\section{Introduction}

The traditional concern of banking regulators and supervisors consists in ensuring the banking system's soundness and in preventing the occurrence of severe banking distress, in order to maintain the fundamental objective of financial stability. In recent years, bank supervision has been directed mainly to the risk profile and soundness of individual credit institutions. This focus on the micro side of the banking system proved wrong, because it was founded on the implicit assumption that the sum of all creditworthy credit institutions forms a solid banking system and that monitoring financial stability of individual financial institutions is a guarantee for the stability of the whole financial system. Micro surveillance has neglected, however, the financial institutions' interconnected nature, both nationally and across borders, the interdependencies manifested both in the interbank market and the securitized products unregulated market.

* Faculty of Finance, Insurance, Banking and Stock Exchanges, The Bucharest University of Economic Studies, Romania (iustinaboitan@yahoo.com). 
The current global crisis has renewed international concerns on reforming key aspects of regulatory and supervisory activities. One of them consists in shifting the center of gravity to macro prudential supervision. In this respect, the Larosiere report (2009) highlighted the highly distinctive, but heavily interconnected nature of micro and macro prudential supervision. The primary objective of micro prudential supervision is to monitor and limit the deterioration of the credit institutions' financial situation, in order to protect customers and prevent the risk of interbank contagion. The macro prudential supervision's objective is broader, consisting of mitigating financial system's imbalances, in order to insure the proper functioning of the economy. The purposes of macro prudential analyses are the overall systemic risk, shocks that have the potential to generate spillover effects and the monitoring of structural and cyclical trends in the financial markets.

In this context, it is outlined the need to deepen research on the development of predictive, forward looking analyses, resulting in the creation and implementation of additional supervisory tools, such as early warning systems, both at national and international institutions level, including, in addition to intrinsic country-specific factors, an international macroeconomic dimension and a component for the potential of contagion between markets and between countries.

Through this empirical approach I intend to develop an important tool for improving the effectiveness of off-site supervisory activity relative to monitoring the quality of loan portfolio. The early warning system was designed for macro prudential purposes, as it must signal the potential for future impairment of the Romanian banking system's aggregated credit portfolio.

It is the first Romanian research study aiming to assess which macroeconomic and bank-specific variables are able to give a warning signal about the impairment of credit portfolio quality. For the Romanian banking system, the National Bank of Romania has developed, until now, only two types of early warning systems: one for estimating the likelihood of currency crises and another designed to quantify the downgrade probability for the CAMEL bank rating.

The rest of the paper is organized as follows. Part 2 reviews the typology of early warning systems operational at present at international level. Part 3 justifies the choice for developing this type of prudential tool, while Part 4 describes the process of construction, testing and validation of the early warning system. Part 5 summarizes, providing evidence on the signal issued by the EWS and concludes.

\section{Review of Currently Operational Early Warning Systems at International Level}

A brief but comprehensive definition of early warning systems (EWS) was provided by Yap (1998, p. 2) : "the basic idea is to monitor key economic variables which would enable policy makers to predict a crisis, allowing them sufficient time to implement 
the appropriate measures to stem the crisis or at the very least minimize its adverse impact".

Early warning systems are sophisticated statistical tools, designed to monitor economic and financial variables and quantify their likelihood of deterioration in order to signal, in an early stage, the imminence of an impairment event. They are seen as mechanisms that transform the information contained in the economic and financial indicators into a measure of future vulnerability.

Economic literature has described two fundamental categories of early warning systems:

- EWSs subordinated to micro surveillance activities, whose main objective is to detect, in an incipient stage, the impairment of credit institutions' financial situation, during the time interval between two on-site inspections. To this end are used, primarily, variables determined on the basis of banks' financial statements, which are designed to duplicate the components of the rating system. Several empirical studies (Thomson 1991; Bernhardsen 2001; Jagtiani, Kolari, Lemieux, Shin 2002; Lanine, Vennet 2005; Halling, Hayden 2006; Brossard, Ducrozet, Roche 2007) have explored the ability of micro-economic indicators to signal and quantify the probability that an individual credit institution became insolvent. This type of early warning system captures the intrinsic factors specific to the activity of a credit institution, able to generate a state of vulnerability or even an episode of banking crisis, through interbank contagion phenomena.

- EWSs which support macro prudential supervision, aiming at identifying the risks a banking system is exposed to and making predictions based on signals provided by macroeconomic variables. Often, macroeconomic turmoil can act as a catalyst, enhancing the latent state of vulnerability of the banking system and creating prerequisites for the spread of difficulties in the entire banking system. A number of studies have empirically tested the causal link between macroeconomic variables and institutional characteristics and the likelihood of a banking crisis (Yap 1998; Hutchison, McDill 1999; Demirguc, Detragiache 1999; Edison 2000; Wong, Leung 2007).

In practice, depending on the features and development status of each banking system, there have been implemented several types of early warning systems, most of them directed to alert on a particular type of vulnerability that can materialize at the level of individual financial institutions (micro- prudential warning systems):

$\rightarrow$ warning systems that estimate the likelihood of a credit institution rating downgrade have the purpose to indicate a deterioration of credit institutions' financial situation in the period between two consecutive on-site inspections. They represent not only a trigger for direct supervisory examinations, but, depending on the extent to which an individual credit institution's rating has deteriorated, they allow the prioritization of the evaluation. As they are based on financial indicators' deteriorations, it is considered that the predictive accuracy will increase in situations of recession.

In this respect, in the U.S. it is used the SCOR model (Statistical Camels Off-site 
Rating) implemented by the Federal Deposit Insurance Corporation since 1998, to replace the previous off-site monitoring system called Capital Asset Earnings Liquidity (CAEL). The model applies a step-wise ordered logit type analysis and estimates, based on banks' quarterly financial reports, the deterioration of their financial performance by calculating a hypothetical CAMELS rating. For each bank it is determined both the probability of composite rating downgrade and of individual ratings associated with each of the six components that are subject of CAMELS rating system. When the downgrade probability exceeds the critical threshold of $35 \%$, the banks will be included in a report, called the Offsite Review List.

In 1995 the Federal Reserve developed an early warning system called SEER (System to Estimate Examination Ratings), consisting of two components: the SEER Rating Model and SEER Risk Rank Model. In order to determine the likelihood of rating downgrade is used the SEER Rating Model, built on a stepwise multinomial logit. The explanatory variables are represented by a series of financial and non-financial indicators, including CAMELS composite ratings. SEER rating is calculated as the sum of the five rating scores, multiplied by the probabilities involved.

$\rightarrow$ bankruptcy prediction systems assume that insolvent credit institutions have a similar behavior in the years preceding the crisis, therefore requiring a careful analysis of their financial statements. The model aims to identify correlations between certain financial ratios and the assumption of a possible bankruptcy. The model is estimated on a sample of troubled banks, then tested on another sample of insolvent banks to verify its accuracy and subsequently used to signal banks whose indicators match those estimated in the model.

One of the main off-site surveillance tools used by the Federal Reserve is SEER risk rank model (System to Estimate Examination Ratings), which allows computing the probability of bankruptcy or severe inadequate capitalization of a bank in a time horizon of two years. The model is based on a probit regression, the estimation period ranging from the first quarter of 1985 and fourth quarter of 1991.

$\rightarrow$ warning systems that estimate the expected loss. They are used in countries which have not experienced banking crises or frequent credit institutions failures and aim at estimating future solvency of banks, by determining the potential future losses. The French Banking Commission introduced in 1998 a system for detecting the risk of banking failure called SAABA (fr. Système d'aide à l'analyse bancaire). The element of originality of this software lies in the ability to process information from 25 separate databases, to determine the quality of credit portfolio for a time horizon of three years. In addition, the SAABA expert system can deal with the risks differentiated according to their nature. Thus, the quantitative risks are addressed on the basis of financial statements while for the qualitative risks (quality of management, of shareholders, soundness of the banking group) are applied scenarios, differentiated for each credit institution. Over time, the SAABA expert system (whose analysis was based on the Cooke solvency ratio) was completed by another two software: SAABASIM (fr. Simulations Sur Le Systeme Bancaire Francais), which became operational in 2002 
and simulates the impact of macroeconomic and microeconomic shocks or changes in the behavior of financial institutions / banking groups in the French banking system, and SAABAMcDO, which became operational in 2004, based on the McDonnough solvency ratio.

$\rightarrow$ other types of early warning systems: GMS (Growth Monitoring System) and REST (Real Estate Stress Test), both off-site monitoring tools being implemented by the Federal Deposit Insurance Corporation (FDIC). GMS identifies those credit institutions which are in a stage of rapid development. The premise of this approach is that a rapid increase in total assets, particularly loans, may signal a risky activity.

REST model was implemented in order to quantify the exposure of banks to real estate sector. Based on data taken from financial reports, it predicts the financial condition of a bank on a time horizon between 3 and 5 years, by assigning a score whose values are between 1 and 5 .

In 2000 the OCC (Office of the Comptroller of the Currency) released a set of early warning tools, known as the Canary Project, which consisted of a series of supervisory tools and statistical models, grouped into four components: benchmarks, the Credit Scope component, barometers of the market and predictive models. Peer Group Risk Models (PGRM) is a type of predictive models applied by the OCC, for forecasting the impact of various economic scenarios on the economic return of banks during a period of three years. Special attention was paid to the benchmark component, whereas it combines supervisors experience with quantitative techniques. Thus, for a predetermined set of 15 financial ratios (six of which aimed at measuring credit risk, four for the interest rate risk and five for the liquidity position) have been established critical thresholds beyond which there is a trend of increasing risk. Benchmarks role is to alert supervisors regarding those operations where there is a pronounced risk appetite. 
Table 1

Instruments for Risk Monitoring and Assessment (selective)

\begin{tabular}{|c|c|c|c|c|}
\hline Country & $\begin{array}{l}\text { Supervisory } \\
\text { Authority }\end{array}$ & Name of instrument & $\begin{array}{l}\text { Release } \\
\text { year }\end{array}$ & Type of instrument \\
\hline \multirow{4}{*}{ Austria } & \multirow{4}{*}{$\begin{array}{l}\text { National Bank of } \\
\text { Austria and } \\
\text { Financial Markets } \\
\text { Authority }\end{array}$} & CAMEL & 1995 & On-site rating system \\
\hline & & $\begin{array}{l}\text { Logit and Cox hazard } \\
\text { rate models }\end{array}$ & 2004 & $\begin{array}{l}\text { Early warning systems that estimate } \\
\text { the probability and time period until } \\
\text { the occurrence of the event }\end{array}$ \\
\hline & & $\begin{array}{l}\text { Value at Risk (credit, } \\
\text { market, operational risk) }\end{array}$ & 2005 & $\begin{array}{l}\text { Structural model to assess the } \\
\text { ability of banks to cover losses }\end{array}$ \\
\hline & & $\begin{array}{l}\text { SRM (Systemic risk } \\
\text { monitor) }\end{array}$ & 2006 & $\begin{array}{l}\text { Monitoring system for systemic } \\
\text { stability by conducting stress tests }\end{array}$ \\
\hline \multirow{2}{*}{$\begin{array}{l}\text { Czech } \\
\text { Republic }\end{array}$} & \multirow{2}{*}{$\begin{array}{l}\text { Czech National } \\
\text { Bank }\end{array}$} & CAMEL & 1998 & On-site rating system \\
\hline & & Logit model & 2001 & $\begin{array}{l}\text { Early warning system for banking } \\
\text { failures }\end{array}$ \\
\hline \multirow{3}{*}{ France } & \multirow{3}{*}{$\begin{array}{l}\text { French Banking } \\
\text { Commission }\end{array}$} & $\begin{array}{l}\text { ORAP (Organisation et } \\
\text { Renforcement de l'Action } \\
\text { Préventive) }\end{array}$ & 1997 & Off-site rating system \\
\hline & & $\begin{array}{l}\text { SAABA (Système d'Aide } \\
\text { à l'Analyse Bancaire) }\end{array}$ & 1998 & Early warning system \\
\hline & & $\begin{array}{l}\text { SIGAL(Système } \\
\text { d'information de } \\
\text { l'Inspection Générale) }\end{array}$ & 2001 & $\begin{array}{l}\text { Information system for supporting } \\
\text { on-site examinations }\end{array}$ \\
\hline Germany & $\begin{array}{l}\text { German Federal } \\
\text { Supervisory Office }\end{array}$ & $\begin{array}{l}\text { BAKIS (BAKred } \\
\text { Information System) }\end{array}$ & 1997 & $\begin{array}{l}\text { System for risk assessment } \\
\text { through peer group analysis }\end{array}$ \\
\hline \multirow[t]{2}{*}{ Italy } & \multirow[t]{2}{*}{ Bank of Italy } & $\begin{array}{l}\text { PATROL (patrimonio, } \\
\text { redditivita, rischiosita, } \\
\text { organizzazione, liquidita) }\end{array}$ & 1993 & Off-site rating system \\
\hline & & $\begin{array}{l}\text { Cox Proportional Hazard } \\
\text { Rate }\end{array}$ & 2000 & Early warning system \\
\hline Netherlands & $\begin{array}{l}\text { De Nederlandsche } \\
\text { Bank }\end{array}$ & $\begin{array}{l}\text { RAST (Risk Analysis } \\
\text { Support Tool) }\end{array}$ & 1999 & System for risk assessment \\
\hline \multirow{3}{*}{ Romania } & \multirow{3}{*}{$\begin{array}{l}\text { National Bank of } \\
\text { Romania }\end{array}$} & CAAMPL & 1999 & On-site rating system \\
\hline & & $\begin{array}{l}\text { Early Warning System } \\
\text { of CAAMPL Rating } \\
\text { Downgrade Events }\end{array}$ & 2007 & $\begin{array}{l}\text { Early warning system (rating } \\
\text { downgrade) }\end{array}$ \\
\hline & & $\begin{array}{l}\text { Early Warning System on } \\
\text { Currency Crises }\end{array}$ & 2006 & $\begin{array}{l}\text { Early warning system (currency } \\
\text { crises) }\end{array}$ \\
\hline U.K. & $\begin{array}{l}\text { Financial Services } \\
\text { Authority }\end{array}$ & $\begin{array}{l}\text { RATE (Risk Assessment, } \\
\text { Tools of Supervision and } \\
\text { Evaluation) }\end{array}$ & 1998 & System for risk assessment \\
\hline
\end{tabular}




\begin{tabular}{|c|c|c|c|c|}
\hline \multirow{7}{*}{ U.S.A. } & & CAMELS & 1980 & On-site rating system \\
\hline & \multirow[b]{3}{*}{ Federal Reserve } & SEER rating & 1995 & $\begin{array}{l}\text { Early warning system (rating } \\
\text { downgrade) }\end{array}$ \\
\hline & & SEER risk rank & 1995 & $\begin{array}{l}\text { Early warning system (banking } \\
\text { failure prediction) }\end{array}$ \\
\hline & & $\begin{array}{l}\text { BOPEC (Bank } \\
\text { subsidiaries covered } \\
\text { by the bank deposit } \\
\text { insurance fund, Other } \\
\text { subsidiaries, Parent } \\
\text { company, Earnings, } \\
\text { Capital) }\end{array}$ & 1979 & $\begin{array}{l}\text { On-site rating system for bank } \\
\text { holdings }\end{array}$ \\
\hline & Occ & Canary Project & 2000 & $\begin{array}{l}\text { Toolbox for risk monitoring and } \\
\text { early warning }\end{array}$ \\
\hline & \multirow{2}{*}{ FDIC } & $\begin{array}{l}\text { SCOR (Statistical } \\
\text { Camels Off-site Rating) }\end{array}$ & 1995 & $\begin{array}{l}\text { Early warning system (rating } \\
\text { downgrade) }\end{array}$ \\
\hline & & $\begin{array}{l}\text { GMS (Growth Monitoring } \\
\text { System) }\end{array}$ & 1990 & $\begin{array}{l}\text { Early warning system for banks with } \\
\text { rapid growth }\end{array}$ \\
\hline
\end{tabular}

Source: Sahajwala R., P. Van den Bergh (2000) "Supervisory Risk Assessment and Early Warning Systems", BCBS Working Paper No.4, p. 5; central banks' sites: www.oenb.at; www.bnr.ro; www.cnb.cz

\section{The Research Assumptions}

Traditionally, the banking crises onset is associated with a high proportion of nonperforming loans in total assets of financial institutions. However, empirical studies have focused mainly on analyzing a broad set of micro and macroeconomic factors, supposedly to be triggers of banking crises, the volume/rate of growth of nonperforming loans or other variables depicting credit portfolio quality being included in the statistical model as explanatory, exogenous variables.

Through this research, it has been proposed another approach, in my opinion more cautious and proactive. It will be created an early warning system able to report, in an incipient stage, not the extreme event of banking crisis, but its main trigger, namely the deterioration of the loan portfolio. Consequently, in this study the variable due and doubtful loans/total assets is endogenous because it was considered that this approach serves better to diminish the risk of fuelling a major episode of vulnerability in the Romanian banking system.

The goal of this study is fully consistent with the latest international tendencies, such as the collaboration between the International Monetary Fund and the Financial Stability Board established in 2009, which consists in performing early warning exercises, focused on financial, economic or fiscal risk analyses and the potential for cross-country contagion. Their purpose, which I have imposed on too for the EWS tested, is not to predict future crises, but to identify, with enough time in advance, those vulnerabilities that can be a trigger of the crises, for the timely adoption of corrective policies. In this study, vulnerabilities are located at the aggregate loan portfolio level. 
The way the credit portfolio for the entire Romanian banking system looks like, in the context of the current financial crisis, is a consequence of the permissive, expansionary attitude of credit institutions, based on a false perception that the economic growth trend will last on long-term. Once the effects of the financial turmoil have propagated into the economy, deepening the already existing imbalances, credit institutions started to experience progressive deterioration of prudential indicators, especially those reflecting the quality of loan portfolio.

Figure 1

\section{Prudential Indicators' Evolution}

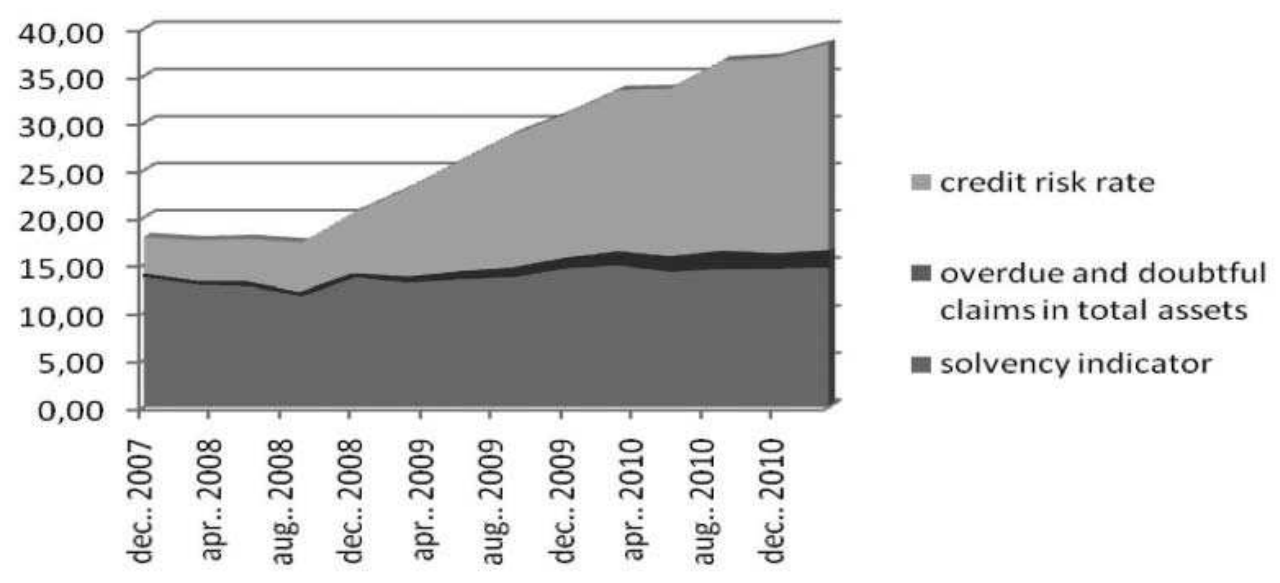

Source: author, data collected from the National Bank of Romania website.

As illustrated by Figure 1, the share of banks' unadjusted exposure from loans and interests classified as doubtful and loss in total loans and interests (the credit risk rate) increased by over $134 \%$ (from $6.52 \%$ at end 2008 to $15.29 \%$ in December 2009), in November 2010 reaching a level of $20.87 \%$, which shows increased growth rate of bad loans. Another representative risk indicator is the share of overdue and doubtful claims (net) in total assets (net), which registered an increase of 248\% in December 2009 to December 2008, and continues to grow at a steady pace, at end 2010 relative to end 2009 recording an advance of nearly $29.74 \%$.

Although the Romanian banking system is well capitalized (the solvency ratio in December 2010 recorded a value of $14.48 \%$, well above the regulatory minimum of $8 \%$ ), and may cover from its own resources any losses incurred by the manifestation of credit risk, and the level of nonperforming loans is manageable, the persistent trend of credit portfolio's quality worsening is perceived as a growing vulnerability the Romanian banking system is exposed to, from the standpoint of financial stability.

As a result, the early warning system that is the subject of the present research was designed to serve as a macro-prudential monitoring tool, being based on a broad 
set of indicators which assess the state of financial stability, the stage of financial liberalization, the dynamics of specific labor market indicators and bank-specific indicators.

I chose to design this type of warning system because, although the Romanian banking system has undergone a comprehensive restructuring and recapitalization process in the early 1990s, it was not affected by banking crisis episodes. At present, its main vulnerability is the moderate but persistent increase in the share of due and doubtful loans in total assets.

\section{The Methodological Approach}

One of the main features that must be met for a EWS to be effective, from the supervisory authorities' standpoint, is that the reasoning underlying the model must be understandable. Several studies argue that supervisors do not trust the "black box" methods (it is the case of computer-assisted prediction methods, such as decision trees, which were used as a means of prediction from the late 1980s and artificial neural networks, which have been applied for the prediction of episodes of bankruptcy since 1990), which classify credit institutions based on a highly complex algorithm.

Consequently, it has been applied an econometric model which constitutes a reference for this type of analyses, namely the limited dependent variable model. The binary logit model developed identifies the presence of a significant correlation between the increasing weight of bad loans in total assets, on the one hand, and a number of macroeconomic and bank-specific variables, on the other hand. One important reason for implementing the logit model resides in the sample of observations, which is not balanced, the frequency of loan portfolio impairment events being lower than those reflecting a good assets quality.

Let $\mathrm{y}$ be a linear function of $\mathrm{x}$ :

$$
y=\alpha+\beta x_{i}
$$

where

$y=$ scalar value measuring the state of distress;

$\mathrm{x}=$ vector of explanatory variables;

$\alpha=$ constant;

$\beta=$ transposed vector of coefficients attributed to each $x_{i}$ variable

Each $\mathrm{x}_{\mathrm{i}}$ regressor will be assigned a $\beta$ coefficient, to measure the individual contribution of each independent variable to the anticipation of the dependent variable's developments. The sign associated with the estimated coefficients for each explanatory variable indicates the relationship established between the probability of occurrence of 
the analyzed event and a change in the explanatory variable considered. The regression coefficients are estimated through an iterative maximum likelihood method.

The probability that the banking system became vulnerable is denoted:

$$
P(y)=P(\alpha+\beta x)
$$

Logistic distribution constrains all estimated probabilities to lie in the range $0-1$. Consequently, the logit model will have the following form:

$$
\mathrm{P}\left(\alpha+\beta^{\prime} \mathrm{x}\right) \frac{1}{1+\mathrm{e}^{-(\alpha+\beta x)}}
$$

For the purpose of this study the dependent variable, denoted by y in the model, is represented by the weight of net overdue and doubtful loans in total assets, as a proxy for the quality of assets. It is a binary variable, taking value 1 for periods characterized by a significant increase in bad loans to total assets, and 0 otherwise. The total assets and not the total loans had been chosen as denominator because the loan portfolio does not represent the only risk exposure of banks. Placements with other banks (mainly interbank deposits) and securities purchased are other types of assets generating credit risk (borrower default), interest rate and exchange rate risk, which can be captured only by reference to total assets.

When the value of the indicator surpass the threshold computed as its average value plus twice the standard deviation, the EWS will provide a signal of distress. This definition of the crisis period has been promoted in the studies of Rojas-Suarez (2001), Bussiere and Fratzscher (2002), Racaru, Copaciu, Lapteacru (2006).

The initial set of explanatory variables included price stability indicators (the consumer price indicator; the ratio of the interest rate charged on loans and the interest rate on deposits of non-bank customers; the exchange rate), a proxy for financial liberalisation (M2 multiplier), labor market indicators (unemployment rate, total economy net wage) and bank-specific indicators, comprising variables for capital adequacy (solvency ratio), profitability (return on assets, return on equity), interbank contagion (interbank liability to total assets), leverage ratio (capital to total assets), measures of credit risk (credit growth) and deposit dynamics (deposit growth). The time period covered ranges between February 2000 and December 2008, using monthly observations.

Explanatory variables have been first seasonally adjusted and tested for unit root, then it had been run univariate models, only with the dependent variable and each of the exogenous ones, to determine which of them should be included in the further expanded model, according to their predictive ability. Each independent variable had been tested for a lag of three, six and twelve months. The rationale for using lags is that, in their absence, explanatory variables would be expressed in current values, indicating therefore that any change of their value will be reflected immediately in the evolution recorded by the dependent variable, which is denied by the economic reality. Several recent 
empirical studies support this reasoning, too. Davis and Karim (2008) believe that one way for improving the discriminatory power of existing early warning systems consists in applying different transformations to independent variables, namely standardizations, lags or interaction variables. Barrell, Davis, Karim and Liadze (2010) point out that to really get a warning signal, the set of predictor variables should be included in the model with a lag of at least one period, rather than the current value, otherwise the model will include only contemporaneous confirmation indicators. Table 2 summarizes only those variables that have passed the statistical tests of goodness-of-fit.

Table 2

Results of Univariate Tests

\begin{tabular}{|l|c|c|c|c|c|}
\hline Variable & $\begin{array}{c}\text { Omnibus } \\
\text { test }\end{array}$ & $\begin{array}{c}\text { Hosmer- } \\
\text { Lemeshow test }\end{array}$ & Wald test & Type 1 error & Type 2 error \\
\hline Solvency ratio, 3m lag & 0.051 & 0.281 & 0.058 & 1 & 0 \\
\hline $\begin{array}{l}\text { Interbank liability/total } \\
\text { assets, 6m lag }\end{array}$ & 0.00 & 0.562 & 0.001 & 0.8 & 0.0208 \\
\hline Leverage ratio, 6m lag & 0.014 & 0.252 & 0.02 & 1 & 0.0104 \\
\hline $\begin{array}{l}\text { Consumer price index, } \\
\text { 6m lag }\end{array}$ & 0.00 & 0.79 & 0.00 & 0.7 & 0.0208 \\
\hline Net wage change & 0.05 & 0.244 & 0.053 & 1 & 0 \\
\hline Deposit growth, 3m lag & 0.036 & 0.476 & 0.053 & 0.9 & 0 \\
\hline
\end{tabular}

Source: results provided by SPSS software

The results of the Omnibus Tests of model coefficients, Hosmer-Lemeshow goodness-offit test and Wald test indicated that the most suitable explanatory variables for anticipating the path of the dependent variable are: the solvency ratio and deposit growth, both with a lag of three months; the ratio of interbank liability to total assets, the leverage ratio and the consumer price index, with a lag of six months; net wage change.

All other variables have to be eliminated because they do not explain the dependent variable in the univariate framework and, hence, will not bring any improvement in the model's predictive accuracy. The six remaining variables have been tested for multicollinearity but the results depicted significant correlation at the 0.01 level between the consumer price index and solvency ratio, leverage ratio and net wage change. As the solvency ratio, leverage ratio and net wage change recorded the highest value for type 1 error (the probability that the early warning model fails in predicting episodes of loan portfolio deterioration), were removed from the list of explanatory variables.

In the following, it had been run a binary logistic regression, with three independent variables: deposit growth, the ratio of interbank liability to total assets and the consumer price index. For estimating the logistic model had been applied three methods, to check for the stability of results. The first method is most straightforward and consists in entering into the equation, from the beginning, of all the relevant predictors. The other 
two methods consist in a stepwise selection of the best predictor variables to be included in the model. The forward stepwise method starts with a model that does not include any of the explanatory variables and adds, successively, the most significant ones, until none of the variables left out of the model would have a statistically significant contribution if added to the model. The backward stepwise method starts with a model that includes all the explanatory variables. At each step, the variable that contributes the least is removed from the model, until all of the predictors in the model are statistically significant. In this analysis, all the three methods chose the same predictor variables, namely the ratio of interbank liability to total assets and the consumer price index, therefore one can be fairly confident that it is a good, reliable model.

Table 3

The Parameter Estimates

\begin{tabular}{|l|c|c|c|c|c|}
\hline & B & Standard error & Wald statistic & Significance & Exp(B) \\
\hline $\begin{array}{l}\text { Interbank liability/total } \\
\text { assets, 6m lag }\end{array}$ & 0.555 & 0.245 & 5.114 & 0.024 & 1.741 \\
\hline $\begin{array}{l}\text { Consumer price index, } \\
\text { 6m lag }\end{array}$ & 1.093 & 0.357 & 9.400 & 0.002 & 2.984 \\
\hline Constant & -114.028 & 36.428 & 9.799 & 0.002 & 0 \\
\hline \begin{tabular}{l} 
Omnibus Test of model coefficients: \\
\hline Hosmer-Lemeshow goodness-of-fit test:
\end{tabular} & 0.461 & & \\
\hline $\begin{array}{l}\text { Area under the ROC curve (AUROC): } \\
\text { Std.error: } 0.049\end{array}$ \\
\hline $\begin{array}{l}\text { Overall percentage of correct predictions: } 93.4 \% \\
\text { Type 1 error: } 0.5 \\
\text { Type 2 error: } 0.0208\end{array}$
\end{tabular}

Source: results provided by SPSS software

According to Wald test, the coefficients of predictor variables included in the equation obtained a probability level lower than the critical value of $5 \%$, therefore they are statistically significant for the model. The coefficient values in the second column will be further used to make predictions.

In order to reveal if the two predictor variables exercise any influence on the dependent variable, in terms of predicting its evolution, it was applied the Omnibus test. As the level of significance obtained is $0 \%$, below the critical threshold of $5 \%$, the null hypothesis is rejected. Therefore, the model performs well and is statistically significant from the standpoint of a causal relationship between the dependent and explanatory variables.

According to Hosmer-Lemeshow test, it is considered that a level of significance below the critical threshold of 5\% is unsatisfactory for the accuracy of the model, indicating a poor fit. In this case, the probability of $46.1 \%$ depicts that the model adequately reflects the data. 
Another output of interest is the percent of overall correct predictions, which recorded a high value, of $93.4 \%$, deriving mainly from model's ability to correctly detect loan portfolio non-impairment events. However, a critical issue for supervisory authority lies in the costs associated to type 1 and type 2 errors. The classification of a loan portfolio impairment event as a non-impairment one (type 1 error) is more expensive than type 2 error, which assumes that the model erroneously reported a damage event, although the loan portfolio quality is satisfactory. For the model tested, the empirical findings reveal that if there are two episodes of loan portfolio impairment, the model would correctly predict only one of them.

From an economic viewpoint, the sign of the coefficients attached to explanatory variables reflects the influence of these variables on the values the dependent variable can take. Thus, the sign ," ${ }^{\text {“ }}$ associated with the consumer price index shows an increasing likelihood of loan portfolio quality deterioration when its value increases. It means that, if the erosion of households' purchasing power overlaps a high degree of banking indebtedness the result would be a compression of households' reimbursing capacity, triggering an increase in the default rate. The positive sign attributed to the ratio of interbank liability to total assets shows a positive correlation between the probability of loan portfolio impairment and interbank contagion.

One last test performed consists in evaluating logit model's predictions accuracy by means of the ROC curve and its surface indicator, AUROC. The ROC curve provides the graphical visualization of the false alarm rate compared to the percentage of correct predictions (sensitivity, hit rate) for all possible values of the cut-off probability. If we choose randomly a point on the ROC curve, with coordinates $(x, y)$, then $x$ is the percentage of false alarms reported by the model which allows obtaining y percentage of correct predictions.

Figure 2

The ROC Curve

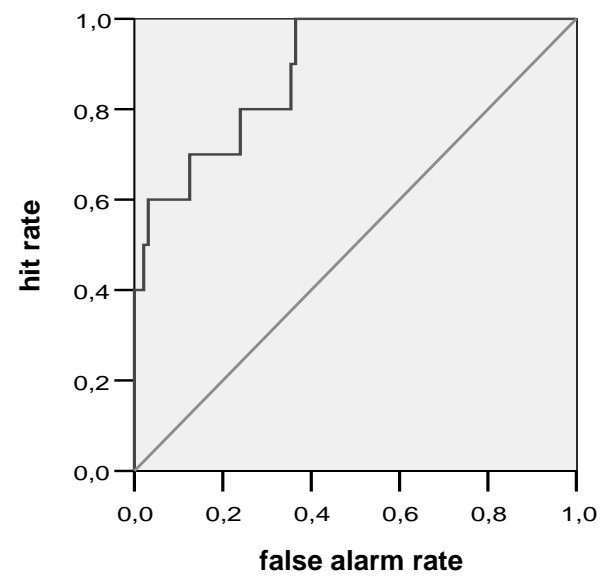

Source: results provided by SPSS software 
The ROC curve surface indicator, called AUROC, quantifies the power of the ROC test, in other words it captures the marginal contribution of the model in anticipating the probability of realization of the event considered. It had been obtained an AUROC of $88.6 \%$, which, according to the economic theory, indicates a good accuracy of predictions.

The robustness and relevance of the predictions generated by any statistical model for monitoring the risks a banking system is exposed to must be validated through an additional out-of-sample test. Moreover, in the economic literature is widely accepted that a causal relationship identified in the initial sample (in sample prediction) should be checked for a new set of observations (out-of-sample), as, on long term, it may prove to be incorrect (spurious).

Statistical models that have passed this ultimate test for validation of predictive power can be used further to make predictions. In this approach, due to constraints imposed on by the limited number of monthly observations (January 2009 - November 2010) included for the out-of-sample test (small sample problem), there is the risk to obtain inflated standard errors, likely to distort the results of statistical tests certifying the accuracy of the model. Hence, I resorted to a trade-off, by expanding the above mentioned sample with data from January 2006 - December 2008. This three years time period recorded no events of credit portfolio deterioration, hence it will not bias the final results.

By running again the logistic regression it can be noticed that the AUROC indicator improves its value, to $90.4 \%$, suggesting that the model benefits from a high, robust discriminatory power.

\section{Concluding Remarks}

In practice, it can be noted the existence of a diversity of early warning models, the distinctive elements being given by the meanings associated to the banking crisis or insolvency events, the time horizon that lies at the origin of predictions (the crisis window), the procedures for explanatory variables selection and the econometric methods implemented (non-parametric, statistical or a mix of both).

In addition, the development of an early warning system is strongly dependent on the intrinsic characteristics of each financial system. In the economic literature there is ample controversy about the optimal set of indicators, able to accurately indicate an imminent impairment of the credit institutions' activity. There have been analyzed the contributions of microeconomic variables, respectively macroeconomic ones, in order to detect, in an early stage, the sources of risk and vulnerability. However, there is not a common denominator because the early warning systems are related to the particularities of an economy, its openness, the level of development and complexity of the financial system, the number, size and concentration of credit institutions and the type of distress that has affected banking system in the past. 
Empirical studies have relied mainly on a standard approach in the construction of EWSs, the explanatory variables included in the analysis following the structure of the rating system ones. In this paper I have used a comprehensive set of macroeconomic variables, which include price stability indicators, a proxy for financial liberalisation, labor market indicators and several bank-specific indicators.

The consumer price index proved to be the most significant macroeconomic variable for explaining short term movements in the Romanian credit institutions' assets quality, while from the bank-specific indicators the ratio of interbank liability to total assets is a good predictor variable.

The purpose of this monitoring tool was to obtain a quantitative assessment of credit portfolio future vulnerability. Using data for December 2010, I have made a forecast for the beginning of 2011 and I found that the out-of-sample probability of an increase in the ratio of due and doubtful loans to total assets is $67.45 \%$. Hence, for the Romanian banking system, the impairment of assets quality still persists.

\section{References}

Barrell R., Davis E. P., Karim D., Liadze I. (2010), "Bank Regulation, Property Prices and Early Warning Systems for Banking Crises in OECD Countries." National Institute of Economic and Social Research, Discussion Paper No. 330.

Bernhardsen E. (2001), "A Model of Bankruptcy Prediction”, Norges Bank Working Paper 10.

Brossard O., Ducrozet F., Roche A. (2007), "An Early Warning Model for EU Banks with Detection of the Adverse Selection Effect." Cahiers du GRES No.2007-08

Bussiere, M., Fratzscher, M., (2002), "Towards a New Early Warning System of Financial Crises", European Central Bank, Working Paper 145, May, 2002

Davis E. P., Karim D. (2008) "Comparing Early Warning Systems for Banking Crises." Journal of Financial Stability, 4 (2008), pp. 89-120.

Demirgüç-Kunt A., Detragiache E. (1998), "The Determinants of Banking Crises in Developing and Developed Countries." IMF Staff Papers Vol.45, No.1.

Edison H. J. (2000), "Do Indicators of Financial Crises Work? An Evaluation of an Early Warning System." Board of Governors of the Federal Reserve System, International Finance Discussion Papers, No.675.

Halling M., Hayden E. (2006), "Bank Failure Prediction: A Two-step Survival Time Approach." The Austrian National Bank.

Hutchison M., McDill K. (1999), "Are All Banking Crises Alike?" University of California, Department of Economics, Working Paper Series, Vol. 99-11.

Jagtiani J. A., Kolari J. W., Lemieux C. M., Shin G. H. (2002), "The Determinants and Early Detection of Inadequate Capitalization of US Commercial Banks."

Lanine G., Vennet R. V. (2005), "Failure Prediction in the Russian Bank Sector with Logit and Trait Recognition Models", Ghent University Working Paper 2005/329.

Larosière J. (2009), "The High-level Group on Financial Supervision in the EU." Report chaired by de Larosière, Brussels, 25 February 2009.

Racaru I., Copaciu M., Lapteacru I. (2006), "Early Warning Systems on Currency Crises." National Bank of Romania Occasional Papers No.5/2006. 
Rojas-Suarez L. (2001), "Can International Capital Standards Strengthen Banks in Emerging Markets?" Institute for International Economics, October 2001.

Sahajwala R., Van den Bergh, P. (2000), "Supervisory Risk Assessment and Early Warning Systems." BCBS Working Paper No.4.

Thomson J. B. (1991), "Predicting Bank Failures in the 1980s." Federal Reserve Bank of Cleveland.

Wong J., Wong E., Leung P. (2007), "A Leading Indicator Model of Banking distress- Developing an Early Warning System for Hong Kong and Other EMEAP Economies." Hong Kong Monetary Authority, Working Paper 22/2007.

Yap J. T. (1998), "Developing an Early Warning System for BoP and Financial Crises: the Case of the Philippines." Philippine Institute for Development Studies, Discussion Paper Series No. 98-40. 